\title{
Et spedbarn med pustevansker og hjertestans
}

\author{
En ti måneder gammel jente ble innlagt med mage- og luftveissympto- \\ mer. I løpet av noen dager utviklet hun respirasjonsproblemer og nevro- \\ logiske symptomer. Deretter skjedde det totalt uventede - hjertestans.
}

Se kommentar side 432

\author{
Finn Greve-Isdahl \\ finn@greve-isdahl.no \\ Barneklinikken \\ Haukeland universitetssykehus \\ Gunhild Holmaas \\ Intensivmedisinsk seksjon \\ Kirurgisk serviceklinikk \\ Haukeland universitetssykehus \\ Christian A. Vedeler \\ Nevrologisk avdeling \\ Haukeland universitetssykehus \\ og \\ Institutt for klinisk medisin \\ Universitetet i Bergen
}

En ti måneder gammel tidligere frisk jente ble innlagt på et sentralsykehus med ett døgns sykehistorie med brekninger og vegring mot inntak av mat og drikke. Etter hvert tilkom heshet og kruppliknende stridor. Hun hadde ingen feber eller diaré.

Ved innleggelsen var pasienten i bra allmenntilstand, og hun ga fin kontakt, men virket slapp og blek. Generell klinisk og nevrologisk undersøkelse var for øvrig normal. Hematologisk profil, infeksjonsprøver, leverenzymer, nyreprøver og syre-base-status var normale. Hurtigtest av respiratorisk syncytialvirus (RSV) var negativ. Man mistenkte viral gastroenteritt eller laryngitt.

I løpet av første observasjonsdøgn fikk jenta økende inspiratorisk stridor, og det ble gitt adrenalin $1 \mathrm{mg} \times 6$ på forstøver. Barnet var fremdeles afebrilt, men hadde brekninger og var i redusert aktivitet. Hun tok til seg noe mat og drikke og kunne sitte i sengen og leke. Det ble observert rødme, spesielt i ansiktet og på ryggen. Tredje dag i sykdomsforløpet var pasientens tilstand betydelig forverret med redusert bevissthet og nedsatt muskeltonus. Hun ga dårlig kontakt og fulgte ikke lenger med blikket. Hun utviklet venstresidig perifer facialisparese og økende dyspné. Det var lett nedsatt respirasjonslyd basalt, og hun hadde i perioder uregelmessig hjerterytme. Man mistenkte pneumoni, og samme dag ble det utført CT thorax som viste bilaterale lungeinfiltrater. På grunn av nedsatt bevissthet ble det tatt cerebral CT som var normal.

Til tross for periodevis uregelmessig hjerterytme var EKG normalt, og uregelmessighetene ble oppfattet som sinusarytmi. Ekko cor viste et normalt hjerte med god kontraktilitet. Lumbalpunksjon ble utført under mistanke om meningitt/encefalitt, men spinalvæsken ble angitt å være normal. Gramfarging av spinalvæsken var negativ, og borreliaantistoff ble ikke påvist. Hematologisk profil, C-reaktivt protein (CRP), leverenzymer, kreatinin, karbamid, serumelektrolytter, glukose og syre-base-status var alle fortsatt innenfor normalområdet.

Påvirket respirasjon og bilaterale lungeinfiltrater kunne tyde på pneumoni. Respiratorisk syncytialt virus ble ikke påvist, men hun kunne ha en annen viral eller bakteriell infeksjon. Forhøyede infeksjonsvariabler ble ikke påvist $\mathrm{i}$ blod. Pasienten utviklet perifer facialisparese, og det var da naturlig å tenke på borreliainfeksjon. Bannwarths syndrom er en meningoencefalitt som kan gi perifer facialisparese. Listeriainfeksjon kan gi hjernestammeaffeksjon. Det var imidlertid ingen tegn til infeksjon ved spinalvæskeundersøkelse. Dyspné kunne også være betinget i nevromuskulær sykdom som akutt perifer nevropati eller myasthenia gravis. Tatt $\mathrm{i}$ betraktning av at det også forelå facialisparese kunne akutt inflammatorisk demyeliniserende polyradikulonevropati (AIDP), som er den vanligste formen for Guillain-Barrés syndrom, være en aktuell differensialdiagnose, men dette ble ansett som lite sannsynlig da spinalvæsken var normal.

På bakgrunn av mistanke om viral eller bakteriell infeksjon fikk barnet tredje dag i sykdomsforløpet $160 \mathrm{mg}$ aciklovir og $800 \mathrm{mg}$ ceftriakson intravenøst som en engangsdose, og man bestemte seg for å overflytte henne til nærmeste universitetssykehus for videre unders $\emptyset$ kelse og behandling. Rett før avreise mistet barnet bevisstheten, oksygenmetningen falt, og EKG viste ventrikkelflimmer. Barnet ble defibrillert og intubert, og hun fikk tilbake sinusrytme og oksygensaturasjon på $98 \%$.
Sannsynligvis fikk barnet akutt autonom påvirkning av hjertet med klinisk hjertestans. Retrospektivt hadde hun hatt rødme som kunne representere autonom påvirkning. Sammenholdt med perifer facialisparese var det sannsynlig at autonom påvirkning kunne være ledd $i$ en affeksjon av det perifere nervesystemet.

Pasienten var intubert og våken ved ankomst universitetssykehuset én time senere. Hun trengte respirasjonsstøtte, men kunne åpne øynene. Hun hadde miotiske pupiller som utvidet seg ved smertestimulering. Det var ikke øyemuskelparese, men hun var mimikkløs og hypoton. Patellarefleksene var utløsbare og plantarrefleksene nedadvendte. Ellers var det arefleksi. Sensibilitet lot seg ikke teste på grunn av manglende kooperasjon. Hun var lett takykard med puls 181 per minutt (90-180) og hadde blodtrykk 90/62 mm Hg (75-100/50-70). Infeksjonsprøver, elektrolytter, syre-base-prøver og laktat var normale. Det ble funnet forhøyet ASAT $628 \mathrm{U} / \mathrm{l}(15-35), \mathrm{LD} 664 \mathrm{U} / \mathrm{l}$ ( < 400), CK $1831 \mathrm{U} / \mathrm{l}$ (35-210), prokalsitonin 2,55 $\mu \mathrm{g} / \mathrm{l}$ $(<0,1)$ og troponin $T 1051 \mu \mathrm{g} / \mathrm{l}<<15)$. EKG var normalt. Ekko cor viste redusert ejeksjonsfraksjon på $35 \%$ (> 60).

Nevrofysiologisk undersøkelse (nevrografi og elektromyografil viste forlengede F-responser, som tydet på nerverotaffeksjon, men det var ellers ikke påvirkning av perifere nerver eller muskulatur. Blodkultur var negativ. Ulike nevroimmunologiske serumprøver, som acetylkolinreseptorantistoff med tanke på myasthenia gravis, gangliosidantistoffer (GQ1b, GM1) med tanke på GuillainBarrés-varianter og myelinassosiert glykoprotein med tanke på paraproteinemisk polynevropati, var negative.

Klinisk forelå det utfall fra det perifere nervesystemet med facialisparese, hypotoni og svake til utslukkede senereflekser. Dette kunne være forenlig med en nevromuskulær sykdom som akutt inflammatorisk demyeliniserende polyradikulonevropati eller myasthenia gravis. Ved akutt inflammatorisk demyeliniserende polyradikulonevropati er autonom affeksjon av varierende alvorlighet til stede hos $60-70 \%$ av pasientene, og hjertearytmi med påfølgende hjertestans og metningsfall, som hos denne pasienten, er beskrevet. Nevrografi og elektromyografi viste forlengede senresponser (F-responser), som tyder på affeksjon av den proksimale delen av perifere nerver. Dette ser man ofte 


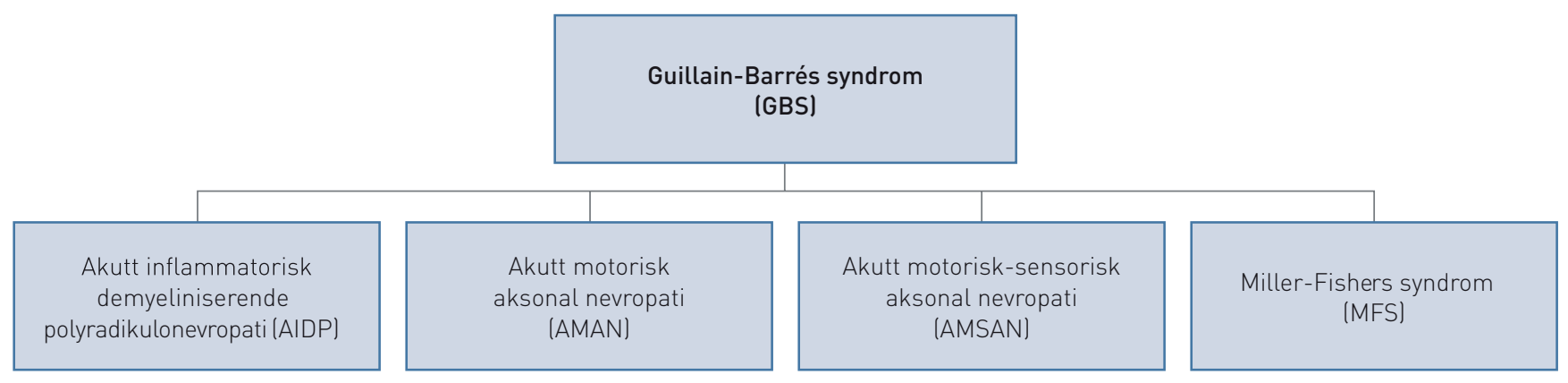

Figur 1 De vanligste subtypene av Guillain-Barrés syndrom

ved akutt inflammatorisk demyeliniserende polyradikulonevropati, da det ved denne sykdommen er vanlig at nerverøttene er affiserte. Acetylkolinreseptorantistoff ble ikke påvist, og sammenholdt med nevrofysiologisk undersøkelse var myasthenia gravis ikke sannsynlig.

Spinalvæsken som ble tatt på sentralsykehuset, var oppgitt å være normal. Det viste seg senere at denne spinalvæskeprøven ikke ble analysert for glukose, celletall og proteininnhold, men kun optisk beskrevet som klar og mikroskopert uten funn. Denne kommunikasjonssvikten om normal spinalvæske før overflytting av pasienten førte til at ny spinalpunksjon ikke ble utført før mye senere. Det antatte negative spinalprøveresultatet var med på å tale mot akutt inflammatorisk demyeliniserende polyradikulonevropati som diagnose initialt.

Negativt gangliosidantistoff (anti-GQ1b) talte mot en eventuell Miller-Fishers-variant av Guillain-Barrés syndrom. Gangliosidantistoff (anti-GM1) kan man se ved motoriske varianter av Guillain-Barrés syndrom, og myelinassosiert glykoproteinantistoff ved paraproteinemisk polynevropati. Disse var negative og gjorde slike former for polynevropati mindre sannsynlige.

Redusert ejeksjonsfraksjon på $35 \%$ og økte verdier av aminotransferase (ASAT), kreatinkinase (CK), laktatdehydrogenase (LD), prokalsitonin og troponin T ble oppfattet som en sannsynlig følge av hjertestans og resuscitering. Det ble ikke utført CK-MB som er den hjertespesifikke fraksjonen av kreatinkinase. Økt kreatinkinase kan tyde på myositt, men det var ikke tegn til myopati ved nevrofysiologisk undersøkelse.

Da infeksiøs sykdom ikke var utelukket, og pasienten var kritisk syk, ble aciklovir 160 $m g \times 3$ intravenøst og ceftriakson $800 \mathrm{mg} \times 1$ intravenøst, som var startet opp på sentralsykehuset, kontinuert. Det ble startet opp med kloramfenikol $200 \mathrm{mg} \times 4$ intravenøst straks og klindamycin $75 \mathrm{mg} \times 4$ intravenøst og oseltamivir $30 \mathrm{mg} \times 2$ per os neste dag. Det var da fire dager siden pasienten ble syk. Samme dag ble pasienten utredet videre med tanke pà eventuell primær infeksiøs sykdom. Virusserologiog PCR-undersøkelser av luftveissekret, inkludert influensa, adenovirus, coxsac- kievirus og respiratorisk syncytialt virus, var negative. PCR-undersøkelser av feces, inkludert enterovirus og rota- og adenovirus, var også normale.

Det kom frem at barnet hadde spist økologisk mat for småbarn. Fagmiljøet på Folkehelseinstituttet mente at to barn i Danmark hadde fått barnebotulisme av økologisk barnemat. Botulinumantitoksin ble derfor gitt natt til sjuende sykdomsdag, men botulinumtoksin i serum ble ikke påvist ved testing på mus ved Veterinærhøgskolen seks dager senere. Folkehelseinstituttet kontaktet sine kolleger i Danmark, som kunne fortelle at den økologiske barnematen ved nærmere undersøkelse ikke var botulismekilden likevel.

Poliovirus i avføringsprøve ble ikke påvist. Det ble tatt ny urinprøve og serum til metabolsk screening som var negativ. Røntgen thorax, tatt noen timer etter hjertestans og intubasjon, viste infiltrater forenlige med aspirasjonspneumoni. Pneumonien avtok ganske raskt, men pasienten hadde ikke krefter nok til å puste selv og var stadig avhengig av respiratorbehandling. Det var ingen spesielle symptomer fra buken, og man begynte med sondemat.

Som ledd $i$ utredningen ble MR-unders $\varnothing$ kelse av abdomen utført fjerde sykdomsdag, og man fant fri luft i buken. Man mistenkte skade på ventrikkel eller tarm, og ved åpen laparotomi fant man en $2,5 \times 1 \mathrm{~cm}$ perforasjon i fundus ventriculi. Dette ble satt i sammenheng med resuscitering, og perforasjonen ble suturert uten komplikasjoner. MR-undersøkelse av cerebrum og medulla spinalis ble tatt med normalt resultat. Ny spinalvæskeundersøkelse 11. sykdomsdag viste normalt antall celler og normal glukose, men sterkt forhøyet proteinkonsentrasjon på 1,01 (N: 0,15-0,50) g/l.

Det ble ved siste spinalvæskeundersøkelse påvist såkalt albuminocytologisk dissosiasjon i spinalvæsken, det vil si økt mengde protein, men normalt antall leukocytter. Dette er et karakteristisk funn ved akutt inflammatorisk demyeliniserende polyradikulonevropati. Proteinkonsentrasjonen kan være normal initialt, men i andre uke av sykdomsforløpet har de fleste pasientene albuminocytologisk dissosiasjon. Ved myasthe- nia gravis og myopati er spinalvæsken normal.

Tilstanden ble 11. sykdomsdag diagnostisert som akutt inflammatorisk demyeliniserende polyradikulonevropati og fra dag 12 fikk hun behandling med intravenøst humant immunglobulin $4 \mathrm{~g}$ per døgn $i$ fem dager. Etter ett døgn fikk hun bedring av mimikk, og i løpet av behandlingsperioden fikk hun ytterligere bedret funksjon av ansikts- og ekstremitetsmuskulatur. Hun ble ekstubert to dager senere og flyttet fra intensivavdelingen til sengepost etter ytterligere to dager. Hun hadde da fremdeles et sentralvenøst kateter $i$ høyre lyske.

Ved mobilisering hadde hun smerter $i$ hoften, og 17. sykdomsdag viste ultralyd en bekkenvenetrombose som initialt ble behandlet med dalteparin dosert i forhold til daglige kontroller av anti-10a-aktivitet med ønsket verdi 0,5-1,0 $\mathrm{IU} / \mathrm{ml}$. Det ble startet opp med warfarin etter tre dagers dalteparinbehandling, og dalteparin ble kontinuert til INR-verdien nådde et akseptabelt nivå. Endelig innstilling av antikoagulasjonsbehandling ble gjort på sentralsykehuset $i$ hjemfylket dit pasienten kom tilbake 33 dager etter at hun ble syk. Pasienten fikk warfarin i seks måneder dosert slik at INR holdt seg rundt 2,5. Hun har etter utskrivning fra sykehuset hatt en jevn fremgang, og ved kontroll seks måneder senere var hun helt restituert uten sekvele.

\section{Diskusjon}

Den vanligste formen for Guillain-Barrés syndrom er akutt inflammatorisk demyeliniserende polyradikulonevropati $(1,2)$ (figur 1$)$. Tilstanden forekommer $i$ alle aldersgrupper, også hos barn. Det er beskrevet Guillain-Barrés syndrom hos pasienter ned til én måneds alder. Insidensen er 1-2 per 100000 per år, men den øker med alderen. Anslagsvis to tredeler av pasientene har kjent forutgående infeksjon, som regel med virus (Epstein-Barr-virus, cytomegalovirus) eller bakterier(Mycoplasma pneumoniae, Campylobacter jejuni).

Hos denne pasienten ble det gjort bred mikrobiologisk utredning av pasienten både med tanke på virus og bakterier. Det eneste positive funnet var forhøyet titer av antistoffer mot Helicobacter pylori (indeks 2,72 
$(<1)$ ). Funnet kan representere maternelle antistoffer, og undersøkelsen er ikke validert for barn. Det finnes undersøkelser som indikerer en sammenheng mellom $\mathrm{H}$ pylori og akutt inflammatorisk demyeliniserende polyradikulonevropati (3), men undersøkelsene er få og små. Betydningen av dette funnet er derfor usikker. Mest sannsynlig har vi ikke påvist et spesifikt utløsende agens, men pasienten hadde forutgående infeksjon før utvikling av pareser og autonom affeksjon.

Det kliniske bildet ved akutt inflammatorisk demyeliniserende polyradikulonevropati er progredierende, som regel symmetriske pareser som ofte kan ramme respirasjonsmuskulaturen slik at pasientene må behandles midlertidig i respirator. Halvparten av pasientene har hjernenerveutfall, oftest perifer facialisparese, som hos vår pasient. Bulbær affeksjon, det vil si affeksjon av nedre hjernenerver, forekommer også. Senerefleksene er svake eller ikke utløsbare som uttrykk for perifer nevrogen affeksjon. Hos vår pasient var patellarefleksene svekket, men ellers var det arefleksi. Videre var det hypotoni i ekstremitetene, som også er til stede ved affeksjon av det perifere nervesystemet. Vanligvis er det også affeksjon av sensoriske nerver med polynevritiform sensibilitetsvekkelse av overflatiske og dype sansekvaliteter distalt i ekstremitetene. Hos vår pasient var det ikke mulig å teste sensibilitet, fordi hun ikke kunne kooperere ved denne undersøkelsen. Ved kun motorisk affeksjon ved Guillain-Barrés syndrom kalles tilstanden akutt aksonal motorisk nevropati, men den er relativt sjelden og forutgås ofte av diaré (Campylobacter jejuni infeksjon). Dette var ikke tilfelle hos vår pasient, og pasienter med akutt aksonal motorisk nevropati kan også ha gangliosid antistoff av type GM1 i serum, som heller ikke ble påvist hos denne pasienten.

Ved nevrofysiologisk undersøkelse av pasienter med akutt inflammatorisk demyeliniserende polyradikulonevropati er det karakteristisk med forlengede F-responser, noe som tyder på proksimal demyelinisering. Normale nerveledningshastigheter kan være til stede tidlig i forløpet. Forlengende F-responser ble påvist fjerde sykdomsdag hos vår pasient. Det ble ikke utført nevrofysiologisk undersøkelse senere i forløpet, men man ville da forventet redusert nerveledningshastighet.

Et annet viktig funn ved akutt inflammatorisk demyeliniserende polyradikulonevropati er forhøyet spinalprotein med bare få eller ingen celler. I første uke av sykdomsprosessen kan imidlertid spinalvæsken være normal Senere i forløpet kommer som regel proteinstigning som følge av transudasjon fra serum på grunn av inflammasjon i nerverøttene. Informasjon om at den første undersøkte spinalvæsken var «normal» gjorde at man ikke tenkte på diagnosen akutt inflammatorisk demyeliniserende polyradikulonevropati da pasienten ankom universitetssykehuset. Klar spinalvæske utelukker kun et høyt celletall og ikke forhøyet protein, så om pasienten allerede tredje sykdomsdag hadde en albuminocytologisk dissosiasjon, er derfor usikkert.

Dysautonomi opptrer hos $60-70 \%$ av pasienter med akutt inflammatorisk demyeliniserende polyradikulonevropati og kan medføre hjertearytmi, hyper- eller hypotensjon, ileus og urinretensjon. Sannsynligvis var dysautonomi årsaken til hjertearytmi med påfølgende hjertestans hos vår pasient. Hun hadde også rødme som man kan se ved autonom affeksjon.

En differensialdiagnose til akutt inflammatorisk demyeliniserende polyradikulonevropati er Miller-Fishers syndrom, som er en form for Guillain-Barrés syndrom med ataksi, oftalmoplegi og arefleksi. Slike pasienter har ofte gangliosidantistoffer av type GQ1b i serum. Dette ble ikke påvist hos vår pasient, som dessuten hadde uttalte pareser forenlig med akutt inflammatorisk demyeliniserende polyradikulonevropati.

Behandling av akutt inflammatorisk demyeliniserende polyradikulonevropati med plasmautskiftning eller intravenøst immunglobulin (IgG) anses som likeverdig, og gis i hovedsak til pasienter med moderate til alvorlige pareser i løpet av de to første ukene av sykdomsforløpet (4). Intravenøst immunglobulin er lettere å administrere, gir færre komplikasjoner og bør derfor foretrekkes hos barn fremfor plasmautskiftning.

Guillain-Barrés syndrom har som regel tre faser: en progredieringsfase av inntil fire ukers varighet, så en platåfase av varierende lengde, hvoretter sykdommen langsomt viser tegn til tilbakegang. De fleste pasientene har god prognose, men vel $10 \%$ får restpareser. Rapportert mortalitet er 3-10\%, oftest på grunn av autonom affeksjon. Prognosen er best for yngre pasienter, hvor sykdommen ikke har medført paralyse, og hvor nevrofysiologisk undersøkelse ikke har vist uttalt aksonal affeksjon. Vår pasient var ung, og til tross for uttalte pareser var det lette nevrofysiologiske utfall. Pasienten var helt restituert seks måneder senere. Det er sjelden at pasienter med Guillain-Barrés syndrom får tilbake- fall av sykdommen, og etter utskrivning fra sykehus kan de følges opp av fastlege, eventuelt av barnelege eller nevrolog.

Det er viktig å huske på akutt inflammatorisk demyeliniserende polyradikulonevropati hos pasienter som utvikler perifere pareser, spesielt etter forutgående infeksjon. Slike pasienter må straks legges inn på sykehus for overvåking og tidlig immunterapi med enten plasmautskiftning eller intravenøst immunglobulin.

Pasientens foreldre har gitt samtykke til at artikkelen blir publisert

\section{Finn Greve-Isdahl (f. 1973)}

er utdannet cand.med. fra Universitetet i Bergen 2004. Han er lege i spesialisering i pediatri ved Barneklinikken, Haukeland universitetssykehus. Han har tidligere jobbet ved Barneavdelingen, Sørlandet sykehus Arendal. Ingen oppgitte interessekonflikter.

\section{Gunhild Holmaas (f. 1966)}

er spesialist i anestesi- og intensivmedisin med subspesialitet $\mathrm{i}$ intensivmedisin. Hun er over lege ved Intensivmedisinsk seksjon, Haukeland universitetssykehus og donoransvarlig lege i Helse Bergen.

Ingen oppgitte interessekonflikter.

\section{Christian A. Vedeler (f. 1958)}

er spesialist i nevrologi ved Nevrologisk avdeling, Haukeland universitetssykehus. Han er også professor ved Universitetet i Bergen og leder av Seksjon for nevrologi der. Han er styremedlem i Foreningen for leger i vitenskapelige stillinger (LVS).

Ingen oppgitte interessekonflikter.

\section{Litteratur}

1. Mellgren SI, Rasmussen M, Vedeler C. Perifere nevropatier. I: Gjerstad L, Helseth E, Rootwelt T. Nevrologi og nevrokirurgi fra barn til voksen. 5 utg. Oslo: Forlaget Vett og Viten, 2010.

2. Vucic S, Kiernan MC, Cornblath DR. Guillain-Barre syndrome: an update. J Clin Neurosci 2009: 16 : 733-41.

3. Kountouras J, Deretzi G, Zavos C et al. Association between Helicobacter pylori infection and acute inflammatory demyelinating polyradiculoneuropathy. Eur J Neurol 2005: 12: 139-43.

4. Vedeler CA, Mellgren SI, Omdal R et al. Intravenøs IgG-behandling av nevromuskulaere sykdommer. Tidsskr Nor Lægeforen 2010; 130: 1717-20.

Mottatt 25.11. 2010, første revisjon innsendt 4.2. 2011, godkjent 7.7. 2011. Medisinsk redaktør Lars Frich. 